\title{
Relationship between Molecular State of Serum HBV-DNA and Clinical Features of Hepatitis B Virus Garriers
}

\author{
Shuichi Sato, Miki Yamada, Yutaka Miyazaki, \\ Keizaburoh Matsuda, Atsushi Kanno, Motoyasu Ishis, \\ Hitoshi OHoRI* and Takayoshi Toyota \\ The Third Department of Internal Medicine, Tohoku \\ University School of Medicine, Sendai 980, and *Sendai \\ Municipal Institute of Public Health, Sendai 980
}

\begin{abstract}
Sato, S., Yamada, M., Miyazaki, Y., Matsuda, K., Kanno, A., IshiI, M., ОновI, H. and Точота, T. Relationship between Molecular State of Serum HBV-DNA and Clinical Features of Hepatitis B Virus Carriers. Tohoku J. Exp. Med., 1993, 171 (4), 309-317—Molecular species of serum hepatitis B virus (HBV)-DNA in HBV carriers were classified by Southern blot hybridization into three types; type I with two bands of $4.0 \mathrm{~kb}$ and $3.2 \mathrm{~kb}$, type II with the two bands of type I plus the smear between $4.0 \mathrm{~kb}$ and $3.2 \mathrm{~kb}$, and type III with a broad band below $4.0 \mathrm{~kb}$. A total of $51 \mathrm{HBV}$ carriers were classified into three groups (group I, $n=19$ with type I; group II, $n=12$ with type II; and group III, $n=20$ with type III). Serum aminotransferase levels of group I were significantly lower than those of groups II and III. Liver pathology revealed that 18 of the $19(94.7 \%)$ group I patients showed nonspecific reactive hepatitis (NSRH), while 11 of the 12 $(91.7 \%)$ group II patients and 19 of the $20(95.0 \%)$ group III patients showed chronic persistent hepatitis (CPH) or chronic active hepatitis (CAH). Immunohistochemical study showed that hepatitis $\mathrm{B}$ core antigen $(\mathrm{HBcAg})$ was localized in the nucleus of hepatocytes in most of patients with type I while it was localized in both the nucleus and cytoplasm in those with types II and III. Since the smear between $4.0 \mathrm{~kb}$ and $3.2 \mathrm{~kb}$ is specifically found in groups II and III, HBV-DNA with this smear may be related to active hepatitis. —— Southern blot hybridization; HBV-DNA; HBV carriers; HBcAg
\end{abstract}

Chronic infection of hepatitis $\mathrm{B}$ virus (HBV) to the liver causes chronic hepatitis, liver cirrhosis and hepatocellular carcinoma. On the other hand, it is accompanied by healthy $\mathrm{HBV}$ carrier state with no or minimal active hepatitis. Because HBV replication is high in healthy carrier state, absence of hepatitis is considered due to the lack of immune response to HBV antigens (Mondelli et al. 1982). However, the possibility that molecular species of HBV may alter the activity of hepatitis still exists.

HBV has a double-stranded DNA (a plus and a minus strands) in the viral particle. Southern blot analysis of HBV-DNA in the sera of $\mathrm{HBV}$ carriers

Received September 13, 1993; revision accepted for publication October 16, 1993. 
demonstrated that several molecular species were detected in serum HBV-DNA (Imazeki et al. 1984; Lok et al. 1985; Scotto et al. 1985). It was stated previously that serum HBV-DNA of HBV carriers could be categorized into three distinct molecular states. These molecular states represented the length of the plus strand of HBV-DNA. The patients who had HBV with incomplete, short plus stranded DNA appeared to have chronic liver disease with active inflammation (Yamada et al. 1993), although the number of patients examined was insufficient to draw a positive conclusion.

This paper addresses the issue of the relationship between the molecular variation of serum HBV-DNA and clinical features of type $B$ hepatitis. The results imply that $\mathrm{HBV}-\mathrm{DNA}$ in the form of a smear between $4.0 \mathrm{~kb}$ and $3.2 \mathrm{~kb}$ by Southern blot analysis is related to active hepatitis.

\section{Materials and Methods}

\section{Patients and serological tests}

Serum samples were obtained from $51 \mathrm{HBV}$ carriers positive for hepatitis B e antigen (40 males and 11 females; $30.2 \pm 13.5$ years of age, mean \pm S.D.) at the time of liver biopsy. Hepatitis $\mathrm{B}$ surface antigen ( $\mathrm{HBsAg}$ ) and antibody against $\mathrm{HBsAg}$ were examined by radioimmunoassay (Abbott Laboratories, North Chicago, IL, USA). Hepatitis B e antigen $(\mathrm{HBeAg})$ and antibody against $\mathrm{HBeAg}(\mathrm{HBeAb})$ were examined by enzyme-linked immunoassay (Abbott Laboratories). The carriers were histologically categorized as follows: asymptomatic carriers with nonspecific reactive hepatitis (NSRH; $n=20$ ), those with chronic persistent hepatitis ( $\mathrm{CPH} ; n=9$ ), and those with chronic active hepatitis (CAH; $n=22$ ). Sera and liver specimens from ten patients with liver diseases negative for all HBV markers were used to determine the specificity of HBV-DNA analysis and immunohistochemistry for $\mathrm{HBcAg}$.

\section{HBV-DNA spot hybridization}

Spot hybridization of serum HBV-DNA was performed using a cloned HBV-DNA labeled with biotin as described previously (Yamada et al. 1993).

\section{Southern blot analysis of HBV-DNA}

Extraction of HBV-DNA from serum and Southern blot analysis were performed as described previously (Yamada et al. 1993). Briefly, the DNAs obtained from sera were electrophoresed through a 1\% agarose gel and transferred to nitrocellulose filter (Advantec Toyo Corp., Tokyo). The filter was dried for $3 \mathrm{hr}$ at $80^{\circ} \mathrm{C}$ and then was prehybridized for $4 \mathrm{hr}$ at $42^{\circ} \mathrm{C}$ in $50 \%$ formamide, $5 \mathrm{X} \mathrm{SSC} \mathrm{(} 1 \mathrm{X} \mathrm{SSC}$ is $150 \mathrm{mM} \mathrm{NaCl}, 15 \mathrm{mM}$ sodium citrate), $5 \mathrm{X}$ Denhardt's solution (1X Denhardt's solution is $0.02 \%$ bovine serum albumin, $0.02 \%$ polyvinylpyrrolidone and $0.02 \%$ Ficoll 400$), 25 \mathrm{mM}$ sodium phosphate $(\mathrm{pH} 6.5)$, and 500 $\mu \mathrm{g} / \mathrm{ml}$ sonicated salmon sperm DNA (Pharmacia, Uppsala, Sweden). The prehybridization solution was removed and then the filter was hybridized for $18 \mathrm{hr}$ at $42^{\circ} \mathrm{C}$ in $45 \%$ formamide, 5X SSC, 1X Denhardt's solution, $20 \mathrm{mM}$ sodium phosphate ( $\mathrm{pH} 6.5$ ), 5\% dextran sulfate, $200 \mu \mathrm{g} / \mathrm{ml}$ sonicated salmon sperm DNA, and a cloned HBV-DNA labeled with biotin (Yamada et al. 1993). The filter was then washed twice in $2 \mathrm{X}$ SSC with $0.1 \%$ sodium dodecyl sulphate (SDS), twice in $0.2 \mathrm{X}$ SSC with $0.1 \%$ SDS for $3 \mathrm{~min}$ at room temperature, twice in $0.16 \mathrm{X}$ SSC with $0.1 \%$ SDS for $15 \mathrm{~min}$ at $50^{\circ} \mathrm{C}$, and once in $2 \mathrm{X}$ SSC. After incubation in a blocking buffer ( $100 \mathrm{mM}$ Tris- $\mathrm{HCl}, 150 \mathrm{mM} \mathrm{NaCl}, 3 \%$ bovine serum albumin, $\mathrm{pH} \mathrm{7.6)} \mathrm{for} 1 \mathrm{hr}$ at $65^{\circ} \mathrm{C}$, the filter was incubated for $10 \mathrm{~min}$ in streptavidinalkaline phosphatase conjugate which was subsequently visualized with nitroblue tetrazolium and 
5-bromo-4-chloro-3-indolylphosphate.

\section{Immunohistochemistry}

Immunohistochemical study was performed as described previously (Kanno et al. 1987). Formalin-fixed and paraffin-embedded sections of the liver were stained for $\mathrm{HBcAg}$ by the avidin-biotin-peroxidase complex $(\mathrm{ABC})$ method (Vectastain $\mathrm{ABC}$ kit, Vector Laboratories, Inc., Burlingame, CA, USA). Each section was initially incubated with $1: 100$ diluted rabbit anti-HBc IgG (DAKO Corp., Santa Barbara, CA, USA) at room temperature for 60 min. After rinsing, the sections were then incubated with $1: 100$ diluted biotinylated goat anti-rabbit IgG (DAKO Corp.) at room temperature for $30 \mathrm{~min}$, followed by incubation in a solution of $1: 500$ diluted ABC. The complex was made visible with diaminobenzidine reaction. Specificity of the reaction was confirmed by absorbing the anti-HBc rabbit serum with purified $\mathrm{HBcAg}$ particles (Onodera et al. 1982), blocking the $\mathrm{HBcAg}$-positive liver specimens with anti-HBc human serum, and staining several liver specimens obtained from HBsAg-negative patients. The percentage of $\mathrm{HBcAg}$ positivity was determined by counting 1,000 hepatocytes under a light microscope.

\section{Statistical analysis}

One-way analysis of variance (ANOVA) test or $\chi^{2}$ test was employed for statistical analysis. A probability of $p<0.05$ was regarded as statistically significant.

\section{Results}

\section{Quantitation of serum HBV-DNA by spot hybridization}

Known concentrations of HBV-DNA were hybridized with a biotin-labeled HBV-DNA probe. The concentrations were roughly correlated with the spot density in the range from 1 to $100 \mathrm{pg} / 50 \mu \mathrm{l}$ (Fig. 1). For Southern blot analysis, the DNA concentration of every serum sample was adjusted to $20 \mathrm{pg} / 50 \mu \mathrm{l}$.

\section{Southern blot hybridization patterns of serum HBV-DNA}

The same three hybridization patterns as those reported previously (Yamada et al. 1993) were reproducibly identified in this study. Type I consisted of two disinct bands of $4.0 \mathrm{~kb}$ and $3.2 \mathrm{~kb}$. Type II consisted of a smear between $4.0 \mathrm{~kb}$ and $3.2 \mathrm{~kb}$ in addition to the two bands of type I. Type III consisted of a broad band below $4.0 \mathrm{~kb}$ (Fig. 2). HBV carriers were classified into three groups (group

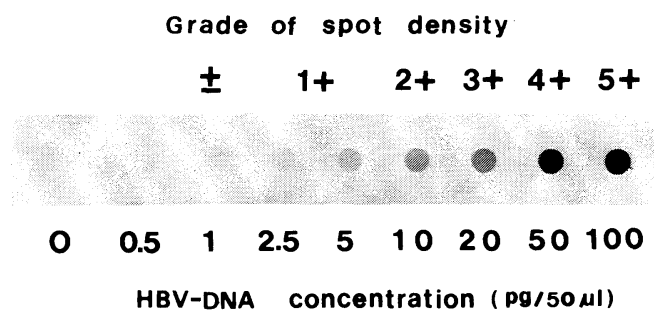

Fig. 1. Spot hybridization of serum HBV-DNA with a biotin-labeled HBV-DNA probe. Known concentrations of HBV-DNA were hybridized with a cloned HBV-DNA labeled with biotin. The grade of, $\pm 1+, 2+, 3+, 4+$ and $5+$ corresponded to $1,2.5 \sim 5,10,20,50$ and $100 \mathrm{pg} / 50 \mu \mathrm{l}$ of HBV-DNA, respectively. 
I, $\mathrm{n}=19$ with type I; group II, $\mathrm{n}=12$ with type II; and group III, $\mathrm{n}=20$ with type III). The sera from 10 control subjects negative for all HBV markers did not show any bands or stains.

\section{Clinical data in groups $I, I I$ and III}

There were no statistical difference on age and sex among these three groups. In the biochemical tests of the liver, the levels of serum asparate aminotransferase (AST) and alanine aminotransferase (ALT) were significantly lower in group I than those in groups II and III. The other biochemical data did not show a statistically significant difference among the three groups (Table 1). The relationship between Southern blot hybridization patterns of serum HBV-DNA and pathologic changes in the liver was also examined. Eighteen of the $19(94.7 \%)$ group I patients had NSRH, while 11 of the $12(91.7 \%)$ group II patients and 19 of $20(95.0 \%)$ group III patients had either $\mathrm{CPH}$ or CAH. In 22 patients with $\mathrm{CAH}, 15$ patients showed type III blotting pattern in their serum HBV-DNAs (Table 2).

\section{Localization of $\mathrm{HBcAg}$ in hepatocytes}

A total of 32 liver specimens from $51 \mathrm{HBV}$ carriers were stained for $\mathrm{HBcAg}$ in hepatocytes. $\mathrm{HBcAg}$ was localized either in the nucleus only (Fig. 3-A) or in both the cytoplasm and nucleus (Fig. 3-B). In 5 of the $6(83.3 \%)$ type I patients, $\mathrm{HBcAg}$ was localized in the nucleus, while in 23 of the $26(88.5 \%)$ patients with types II and III, $\mathrm{HBcAg}$ was localized in both the cytoplasm and nucleus. Furthermore, HBcAg was dominated in the cytoplasm in type III (Table 3).

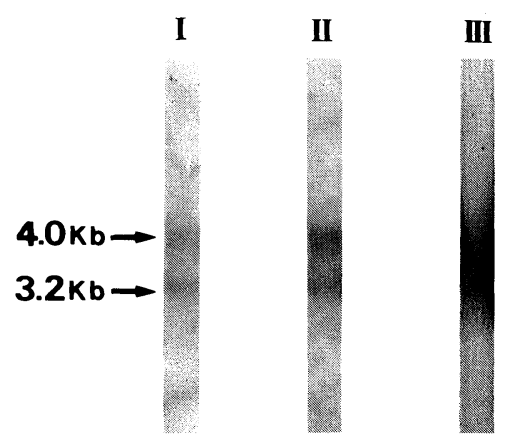

Fig. 2. Three typical Southern blot hybridization patterns of serum HBV-DNA. The DNAs were electrophoresed through a $1 \%$ agarose gel, blotted onto nitrocellulose filter, and hybridized with a cloned HBV-DNA labeled with biotin. I, II and III indicate type I, type II and type III, respectively. 
TABLE 1. Clinical data of patients in each group

\begin{tabular}{|c|c|c|c|c|}
\hline \multicolumn{5}{|c|}{ Patient } \\
\hline & $\begin{array}{l}\text { Group I } \\
(n=19)\end{array}$ & $\begin{array}{c}\text { Group II } \\
(n=12)\end{array}$ & $\begin{array}{c}\text { Group III } \\
(n=20)\end{array}$ & $\underset{\text { test }}{\text { ANOVA }}$ \\
\hline Age (years) & $27.0 \pm 18.1$ & $36.3 \pm \quad 8.8$ & $29.7 \pm \quad 9.3$ & n.s \\
\hline $\operatorname{Sex}(M / F)$ & $14 / 5$ & $9 / 3$ & $17 / 3$ & n.s* \\
\hline T.B. $(\mathrm{mg} / 100 \mathrm{ml})$ & $0.8 \pm 0.2$ & $0.9 \pm \quad 0.4$ & $0.9 \pm \quad 0.3$ & n.s \\
\hline AST (IU/liter) & $27.2 \pm 11.8$ & $191.7 \pm 211.6$ & $131.4 \pm 121.8$ & $p<0.01$ \\
\hline ALT (IU/liter) & $26.5 \pm 14.3$ & $26.0 \pm 169.5$ & $200.4 \pm 159.5$ & $p<0.01$ \\
\hline LDH (IU/liter) & $390.5 \pm 88.9$ & $44.8 \pm 115.8$ & $411.4 \pm 86.5$ & n.s \\
\hline ALP (IU/liter) & $147.6 \pm 80.1$ & $112.6 \pm 33.7$ & $114.7 \pm 52.6$ & n.s \\
\hline$\gamma$-GTP (IU/liter) & $34.0 \pm 20.8$ & $60.9 \pm 54.9$ & $58.7 \pm 37.7$ & n.s \\
\hline ChE (IU/liter) & $314.1 \pm 58.2$ & $277.3 \pm 58.1$ & $264.6 \pm 46.6$ & n.s \\
\hline T.P. $(\mathrm{g} / 100 \mathrm{ml})$ & $7.3 \pm 0.4$ & $7.6 \pm \quad 0.4$ & $7.5 \pm \quad 0.5$ & n.s \\
\hline HBV-DNA (grade) & $2.6 \pm 0.5$ & $2.6 \pm \quad 0.9$ & $2.3 \pm \quad 1.3$ & n.s \\
\hline
\end{tabular}

Results are expressed as mean \pm s.D. n.s., not significant. ${ }^{*} \chi^{2}$ test

TABLE 2. Pathological diagnosis and Southern blot hybridization patterns of serum $\mathrm{HBV}-\mathrm{DNA}$

\begin{tabular}{ccccc}
\hline \multirow{2}{*}{ Group } & \multirow{2}{*}{ No. tested } & \multicolumn{3}{c}{ Pathological diagnosis } \\
& & NSRH & CPH & CAH \\
\hline I & 19 & 18 & 1 & 0 \\
& & $(94.7 \%)$ & $(5.3 \%)$ & $\left(\begin{array}{c}0 \%) \\
\text { II }\end{array}\right.$ \\
& \multirow{2}{*}{ III } & 1 & 4 & 7 \\
& 20 & $(8.3 \%)$ & $(33.4 \%)$ & $(58.3 \%)$ \\
& & 1 & 4 & 15 \\
& & $(5.0 \%)$ & $(20.0 \%)$ & $(75.0 \%)$ \\
\hline
\end{tabular}

$\mathrm{NSRH}$, nonspecific reactive hepatitis; $\mathrm{CPH}$, chronic persistent hepatitis; $\mathrm{CAH}$, chronic active hepatitis.

$\chi^{2}=40.5(p<0.001)$

Changes of serum ALT levels and Southern blot pattern of HBV-DNA in the sera from a $H B V$ carrier

In one HBV carrier whose sera were sequentially analysed for biochemical, serological, and virological features, his HBV-DNA at first showed type I when serum ALT levels were slightly elevated. With flare-up of hepatitis, HBV-DNA turned to type II and liver biopsy revealed chronic active hepatitis (Fig. 4).

\section{Discussion}

This paper presented the relationship between the molecular state of serum HBV-DNA and clinical features of HBV carriers. The serum HBV-DNAs were 


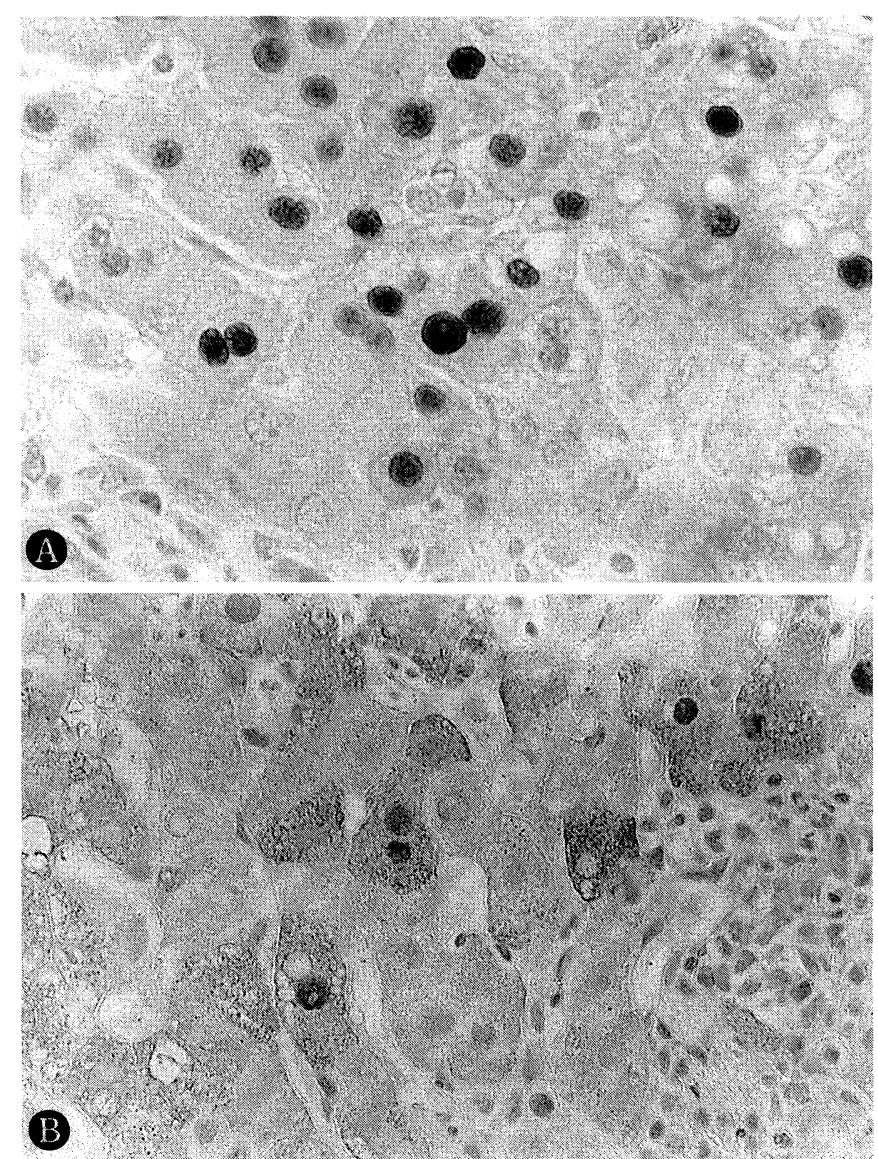

Fig. 3. (A) Nuclear $\mathrm{HBcAg}$ expression in hepatocytes of $\mathrm{HBV}$ carrier with nonspecific reactive hepatitis. Immunoperoxidase staining, $\times 200$.

(B) Nuclear and cytoplasmic HBcAg expression in hepatocytes of HBV carrier with chronic active hepatitis. Immunoperoxidase staining, $\times 200$.

TABLE 3. HBcAg in hepatocytes and Southern blot hybridization patterns of serum $H B V-D N A$

\begin{tabular}{ccccc}
\hline \multirow{2}{*}{ Group } & \multirow{2}{*}{ No. tested } & \multicolumn{3}{c}{ HBcAg localization } \\
& & $\mathrm{N}$ only & $\mathrm{N}>\mathrm{C}$ & $\mathrm{N}<\mathrm{C}$ \\
\hline I & 6 & 5 & 1 & 0 \\
& & $(83.3 \%)$ & $(16.7 \%)$ & $(0 \%)$ \\
II & 9 & 1 & 3 & 5 \\
& & $(11.1 \%)$ & $(33.4 \%)$ & $(55.5 \%)$ \\
III & 17 & 2 & 2 & 13 \\
& & $(11.8 \%)$ & $(11.8 \%)$ & $(76.4 \%)$ \\
\hline
\end{tabular}

$\mathrm{N}$, nucleus; C, cytoplasm. $\mathrm{N}>\mathrm{C}$ means $\mathrm{HBcAg}$ is more abundant in the nucleus than the cytoplasm. $\chi^{2}=16.1(p<0.005)$ 


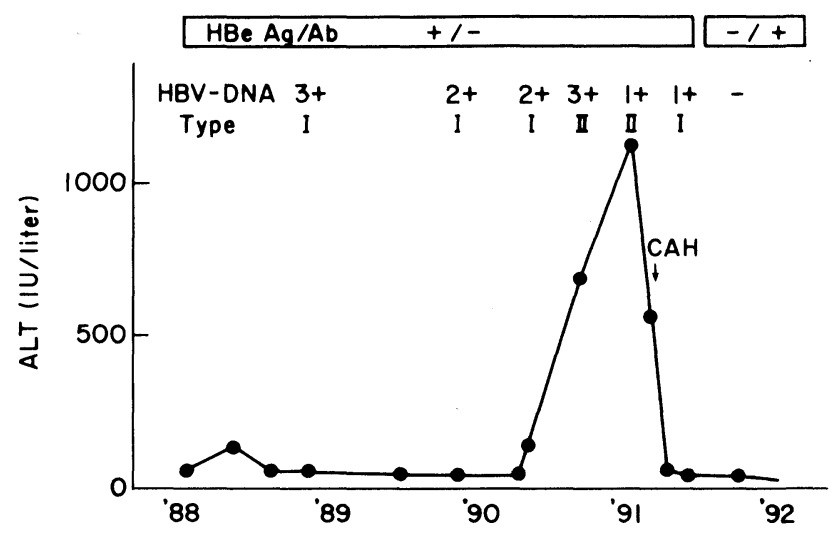

Fig. 4. Changes of serum ALT levels and Southern blot pattern of HBV-DNA in the sera from a HBV carrier who experienced exacerbation of hepatitis.

categorized previously into three types by Southern blot hybridization. These three types did not represent the different amount of DNA but a different molecular state of HBV-DNA; $4.0 \mathrm{~kb}$ form was a relaxed circular, fully doublestranded DNA, $3.2 \mathrm{~kb}$ form was a linear, fully double-stranded DNA, and the smear between $4.0 \mathrm{~kb}$ and $3.2 \mathrm{~kb}$ was the sum of relaxed circular, double-stranded DNAs with various length of plus strands (Yamada et al. 1993). Viral particles with the DNA molecules are eventually secreted into blood at any phase of intracellular assembly of HBV-DNA. Therefore, these three types may represent the different replication state of $\mathrm{HBV}$ in hepatocytes.

Serum aminotransaminase levels of groups II and III were significantly higher than those of group I. Histologically, group I patients had mainly minimal hepatitis, while groups II and III patients had active hepatocyte injury. $\mathrm{HBcAg}$ was present in the cytoplasm in patients with types II and III, while it was mainly in the nucleus in those with type I. These results indicate that types II and III relate to active hepatitis. Since the smear between $4.0 \mathrm{~kb}$ and $3.2 \mathrm{~kb}$ is specific in types II and III, this smear may be related to active hepatitis.

The exact mechanism of hepatocyte injury remains to be elucidated. $\mathrm{HBcAg}$ is present either in the nucleus or in the cytoplasm (Yamada and Nakane 1977; Akiba et al. 1987). In addition, $\mathrm{HBcAg}$ is localized mainly in the cytoplasm and/or on the plasma membrane when hepatocytes are damaged by lymphocytes (Chu and Liaw 1987; Hsu et al. 1987; Kojima et al. 1987). Therefore, replication of $\mathrm{HBV}$ in hepatocytes may result in expression of $\mathrm{HBcAg}$ on hepatocyte surface together with HLA-class I antigen. These two antigens will be recognized by cytotoxic $\mathrm{T}$ lymphocytes and subsequent injury of hepatocytes is induced (Montano et al. 1982; Chu and Liaw 1987; Ferrari et al. 1987). Our result that $\mathrm{HBcAg}$ in hepatocytes from patients who had types II and III HBV-DNA was localized in the cytoplasm also supports the contention that the smear between 4.0 
$\mathrm{kb}$ and $3.2 \mathrm{~kb}$ is related to immune-mediated lysis of hepatocytes infected with HBV.

In this study, full length of relaxed circular and linear DNAs were found in viral particles from NSRH patient. On the other hand, viral particles contained heterogeneous DNA molecules with complete minus strands and partial plus strands in most cases with active hepatitis (Table 2). Imazeki et al. (1984) and Fowler et al. (1984) demonstrated that there was a full length of HBV molecules in serum. On the other hand, viral particles with partially double-stranded DNA molecules (Kam et al. 1982) or those with complete minus strands without associated plus strands (Scotto et al. 1985) were also found in serum. Clinical significance of these species of virus has not been evaluated, and the reason why packaging of such heterogeneous HBV-DNA into viral particles is not known. It is well known that increased HBV replication occurs immediately before hepatocyte injury (Tong et al. 1987). In this highly replicative phase, the incomplete plus strands of HBV may be packaged into viral particles before complete synthesis of the plus strands occurs.

Our results clearly demonstrated the close association of the molecular state of HBV-DNA in serum and the activity of hepatitis. Therefore, analysis of serum $\mathrm{HBV}-\mathrm{DNA}$ by Southern blot hybridization is a useful marker for viral replication and the degree of hepatitis.

\section{References}

1) Akiba, T., Nakayama, H., Miyazaki, Y., Kanno, A., Ishii, M. \& Ohori, H. (1987) Relationship between the replication of hepatitis B virus and the localization of virus nucleocapsid antigen ( $\mathrm{HBcAg})$ in hepatocytes. J. Gen. Virol., 68, 871-877.

2) Chu, C.M. \& Liaw, Y.F. (1987) Intrahepatic distribution of hepatitis B surface and core antigens in chronic hepatitis B virus infection: Hepatocyte with cytoplasmic/ membranous hepatitis B core antigen as a possible target for immune hepatocytolysis. Gastroenterology, 92, 220-225.

3) Ferrari, C., Penna, A., Giuberti, T., Tong, M.J., Ribera, E., Fiaccadori, F. \& Chisari, F.V. (1987) Intrahepatic, nucleocapsid antigen-specific $\mathrm{T}$ cells in chronic active hepatitis B. J. Immunol., 139, 2050-2058.

4) Fowler, M.J.F., Monjardino, J., Weller, I.V.D., Lok, A.S.F. \& Thomas, H.C. (1984) Analysis of the molecular state of HBV-DNA in the liver and serum of patients with chronic hepatitis or primary liver cell carcinoma and the effect of therapy with adenine arabinoside. Gut, 25, 611-618.

5) Hsu, H.C., Su, I.J., Lai, M.Y., Chen, D.S., Chang, M.H., Chung, M.H. \& Sung, J.L. (1987) Biologic and prognostic significance of hepatocyte hepatitis B core antigen expressions in the natural course of chronic hepatitis B virus infection. J.Hepatol., 5, 45-50.

6) Imazeki, F., Omata, M., Yokosuka, O., Matsuyama, Y., Ito, Y., Uchiumi, K., Mori, J., Tanaka, A., Hirota, K., Tagawa, M. \& Okuda, K. (1984) Analysis of hepatitis B virus DNA in the liver and serum by Southern blot hybridization. Acta Hepatol. $J p n ., 25,855-858$. (in Japanese with English abstract)

7) Kam, W., Rall, L.B., Smuckler, E.A., chmid, R. \& Rutter, W.J. (1982) Hepatitis B virus DNA in liver and serum of asymptomatic carriers. Proc. Natl. Acad. Sci. USA, 79, $7522-7526$. 
8) Kanno, A., Ohori, H., Matsuda, K., Nakayama, H., Miyazaki, Y., Ishii, M., Suzuki, H., Ohtsuki, M. \& Goto, Y. (1987) Virological significance of HBeAg subtypes (HBeAg/ 1 and $\mathrm{HBeAg} / 2)$ in patients with type B hepatitis. Hepatology, 7, 15-19.

9) Kojima, T., Bloemen, J. \& Desmet, V.J. (1987) Immune electron microscopic demonstration of hepatitis $\mathrm{B}$ core antigen $(\mathrm{HBcAg})$ in liver cell plasma membranes. Liver, 7, 191-200.

10) Lok, A.S.F., Karayiannis, P., Jowett, T.P., Fowler, M.J.F., Farci, P., Monjardino, J. \& Thomas, H.C. (1985) Studies of HBV replication during acute hepatitis followed by recovery and acute hepatitis progressing to chronic disease. J. Hepatol., 1, 671679 .

11) Mondelli, M., Vergani, G.M., Alberti, A., Vergani, D., Portmann, B., Eddlestone, A.L. W.F. \& Williams, R. (1982) Specificity of lymphocyte cytotoxicity to autologous hepatocytes in chronic hepatitis B virus infection: Evidence that $\mathrm{T}$ cell are directed against HBV core antigen expressed on hepatocytes. J. Immunol., 129, 2773-2778.

12) Montano, L., Miescher, G.C., Goodall, A.H., Wiedmann, K.H., Janossy, G. \& Thomas, H.C. (1982) Hepatitis B virus and HLA antigen display in the liver during chronic hepatitis B virus infection. Hepatology, 2, 557-561.

13) Onodera, S., Ohori, H., Yamaki, M. \& Ishida, N. (1982) Electron microscopy of human hepatitis B virus core by negative staining-carbon film technique. J. Med. Virol., 10, 147-155.

14) Scotto, J., Hadchouel, M., Wain-Hobson, S., Sonigo, P., Courouce, A.M., Tiollais, P. \& Brechot, C. (1985) Hepatitis B virus DNA in Dane particles: Evidence for the presence of replicative intermediates. J. Infect. Dis., 151, 610-617.

15) Tong, M.J., Sampliner, R.E., Govindarajan, S. \& Co, R.L. (1987) Spontaneous reactivation of hepatitis $B$ in Chinese patients with $\mathrm{HBs} A$-positive chronic active hepatitis. Hepatology, 7, 713-718.

16) Yamada, G. \& Nakane, P.K. (1977) Hepatitis B core and surface antigens in liver tissue: Light and electron microscopic localization by the peroxidase-labeled antibody method. Lab. Invest., 36, 649-659.

17) Yamada, M., Ishii, M., Miura, M., Sato, S., Kanno, A., Ohori, H. \& Toyota, T. (1993) Three distinct Southern blot hybridization patterns of HBV-DNA in the sera of HBV carriers. Tohoku J. Exp. Med., 170, 219-228. 